\title{
Article \\ High Seedling Mortality of Scots Pine Caused by Heterobasidion annosum s.s.
}

\author{
Tuula Piri *, Eeva J. Vainio, Heikki Nuorteva (D) and Jarkko Hantula
}

Citation: Piri, T.; Vainio, E.J.;

Nuorteva, H.; Hantula, J. High Seedling Mortality of Scots Pine Caused by Heterobasidion annosum s.s. Forests 2021,12, 1289. https:// doi.org/10.3390/f12091289

Academic Editor: Jolanda Roux

Received: 3 August 2021

Accepted: 17 September 2021

Published: 19 September 2021

Publisher's Note: MDPI stays neutral with regard to jurisdictional claims in published maps and institutional affiliations.

Copyright: (c) 2021 by the authors. Licensee MDPI, Basel, Switzerland. This article is an open access article distributed under the terms and conditions of the Creative Commons Attribution (CC BY) license (https:/ / creativecommons.org/licenses/by/ $4.0 /)$.
Natural Resources Institute Finland (Luke), Latokartanonkaari 9, FI-00790 Helsinki, Finland; eeva.vainio@luke.fi (E.J.V.); heikki.nuorteva@luke.fi (H.N.); jarkko.hantula@luke.fi (J.H.)

* Correspondence: tuula.piri@luke.fi; Tel.: +35-85-03912453

\begin{abstract}
This study provides new information on the infection biology and pathogenicity of an important root-rot fungus, Heterobasidion annosum sensu stricto (Fr.) Bref., through a detailed examination of the vegetative spread of clonal individuals and their capacity to produce fruiting bodies on young pine seedlings. The seedlings were planted in a clear-cutting area (c. 1.2 ha in size) after a pine generation that showed slight external symptoms of Heterobasidion root rot. The first dead seedlings were found five years after planting and during a nine-year monitoring period; nearly 600 seedlings were killed by H. annosum s.s. in 48 individual disease centers. Based on pairing tests of 482 isolates, 117 different $H$. annosum s.s. genotypes were identified. On average, 2.9 genotypes occurred in a single disease center. The extensive secondary spread of genotypes within root systems (up to 48 pine seedlings infected by the same genotype) resulted in annually expanding disease centers. In addition, more than half of the seedlings killed by H. annosum s.s. produced perennial fruiting bodies thus providing air-borne inoculum. The risk of spore infection should be taken into account in any type of cutting operation in young pine stands. Moreover, new control measures directed towards the secondary spread of $H$. annosum s.s. in pine regeneration are urgently needed in order to maintain the productivity of the pine forest on infested sites.
\end{abstract}

Keywords: Heterobasidion root rot; genet; fruiting body; Pinus sylvestris; seedling

\section{Introduction}

Root and butt rot caused by Heterobasidion annosum (Fr.) Bref. sensu lato is one of the most serious diseases of coniferous forests in the Northern Hemisphere [1]. In Europe, three Heterobasidion species with different host tree preferences are present: Heterobasidion parviporum Niemelä and Korhonen prefer Picea abies (L.) Karsten, H. abietinum Niemelä and Korhonen Abies species and H. annosum sensu stricto (Fr.) Bref. Pinus species but attack many other tree species as well [1,2]. In the Nordic countries, Heterobasidion root rot is caused by either $H$. annosum s.s. or $H$. parviporum. In Finland, H. parviporum is widely distributed throughout the country while H. annosum s.s. is more scattered and limited to the south [3]. In recent decades, however, more young pine stands with incipient Heterobasidion root rot have been observed in southwestern and central parts of Finland where the disease has not been observed previously.

Conifer stands initially become infected by Heterobasidion sp. when fungal spores come into contact with a freshly exposed wood substrate. Stumps created during the warm season when the fungus is sporulating act as the main entry point for Heterobasidion infections. Also logging wounds expose Norway spruce stands to primary spore infection, while in Scots pine stands wounds might not be a significant infection pathway for H. annosum s.s. [4]. After colonization, the Heterobasidion mycelium spreads from a primary infected stump or tree via root contact and infects nearby growing trees [5].

In the northern part of the distribution area of Heterobasidion spp., the risk of spore infection is low in winter, when low temperatures and snow covering the fruiting bodies reduce spore production and dispersal. Spore production occurs when the average daily 
temperature exceeds $+5^{\circ} \mathrm{C}$, and the infection risk increases rapidly being at its highest from late June to the end of August [5,6]. As a result of global warming, the sporulation period of Heterobasidion spp. is lengthening, which increases the risk of the disease spreading in boreal forests [7]. Most likely, the main reason for the spread of Heterobasidion root rot into new, initially healthy pine sites are logging operations carried out without stump treatment during the period when the risk of spore infection is high. For example, in western Finland, stump treatment in pine stands has been broadly practiced for less than 10 years, while summer cuttings in pine stands have been carried out for more than 50 years. Before that, logging operations were conducted almost exclusively during the winter months when the chance of infection is low.

A single Heterobasidion genotype can live for more than a hundred years and spread from one tree generation to the next [8]. As a result of the vegetative tree-to-tree spread, Scots pine stands infected by $H$. annosum s.s. are characterized by disease centers with dead and dying trees. Often, the disease centers continue to expand until they reach trees resisting the Heterobasidion infection or, on badly infested sites, already infected trees of an adjacent disease center. Although H. annosum s.s. can infect Scots pine trees of all ages, mature pines are less likely to die from Heterobasidion infection than young trees [9,10]. The fungus can live for decades in the root system of mature pines without showing any external disease symptoms on the tree [11-14].

The wide range of host species makes the control of $H$. annosum s.s. difficult. On sites infested by $H$. annosum s.s., only a pure deciduous tree rotation using birch (Betula pendula Roth and B. pubescens Ehrh.) or aspen (Populus tremula L.) remains safe from notable damage [15-17]. However, in practical forestry, a change of tree species is only seldom possible due to the different site requirements of pine and deciduous trees. Thus, on poor forest sites, forest owners rarely have other options than to continue growing Scots pine despite the expected Heterobasidion damage. On such sites, the disease may become chronic and the damage tends to increase from generation to generation.

On several pine sites at the edge of the distribution range of H. annosum s.s., as in southwestern and central Finland, the disease history is relatively short. Most pine stands are the second tree generation infected by the fungus. So far, very little is known about the progression and extent of root rot in these pine stands of the second diseased generation. To meet this need for knowledge, we have followed the spread of individual Heterobasidion genotypes and the progression of the disease for 13 years in a young Scots pine stand established on a site infected during the previous tree generation. Detailed information on the fungal population structure and spreading pattern starting from the first Heterobasidion infections of pine seedlings will help to assess the impact of Heterobasidion root rot on future stand productivity and improve disease control in young pine regenerations.

\section{Materials and Methods}

\subsection{Study Site}

The experimental Scots pine stand, c. 1.2 ha in size, is located in the municipality of Loppi in southern Finland in Luke's (Natural Resources Institute Finland) experimental forest $\left(60^{\circ} 36.788^{\prime} \mathrm{N}, 24^{\circ} 25.526^{\prime} \mathrm{E}\right) 136 \mathrm{~m}$ above sea level. The site is a sub-xeric sandy heath classified as a Vaccinium vitis-idea (VT) forest site type [18]. The effective temperature sum (threshold $>+5{ }^{\circ} \mathrm{C}$ ) is 1224 d.d. degree days. At the beginning of the study, the existing pine stand was c. 80 years old and showed some external signs (few dead pines) indicating Heterobasidion root rot.

\subsection{Monitoring Heterobasidion Root Rot in the Previous Tree Generation}

In April 2005, the 80-year-old pine stand was systematically surveyed and the incidence of Heterobasidion root rot was assessed based on the external condition of the trees. Pine trees with thin or chlorotic crowns, reduced height growth, or distress cones were classified as infected by H. annosum s.s. In total, nine separated disease centers with one to nine mature trees in poor condition were found [19]. All dead and infected trees, as 
well as one or two of the nearest healthy-looking mature trees, were marked with a label below the stump height. During clear-cutting in July 2005, the stumps of all unmarked trees were treated with urea to prevent new Heterobasidion infections. After harvesting, the stumps of the marked trees were sampled by cutting a disc about $10 \mathrm{~cm}$ below the stump surface. In total, 27, 24, and 10 trees classified as dead, infected, or healthy, respectively, were sampled. The sample discs were washed under running water and incubated in plastic bags at room temperature for 14 days. The discs were checked every 2-3 days under a binocular dissection microscope for Heterobasidion conidiophores as indicators of Heterobasidion infection in the tree. Heterobasidion mycelia including conidiophores were isolated from the sample discs with the aid of tweezers and transferred to Petri dishes containing malt extract agar (MEA; $2 \%$ w/v malt extract and 1.5\% w/v agar). The isolates were subcultured and stored at $4{ }^{\circ} \mathrm{C}$ on MEA for later pairing tests.

In order to obtain detailed information about the transfer of $H$. annosum s.s. from the previous pine generation (referred to as generation 1 ) to the subsequent pine regeneration (referred to as generation 2), a circular study plot $20 \mathrm{~m}$ in diameter was established in the most infested part of the stand after the clear-cutting. In the plot, the stumps of the previous tree generation (generation 1), including 58 stumps created during clear-cutting in 2005 (56 pine stumps and one birch and spruce stump) and 53 older stumps created at thinnings before the clear-cutting (all pine stumps), as well as eight stumps of seed trees left from the older tree generation (referred to as generation 0 ) until the establishment of seedlings of a new tree generation (generation 1), were mapped and sampled with the aid of an increment borer as described earlier [20]. The samples were taken from the body of old thinning and seed tree stumps, and from the base of the three to four main roots of final cutting stumps. The wood cores were cultured on MEA and Heterobasidion mycelia growing out of wood samples were isolated. Because core samples from some final cutting stumps with apparent signs of Heterobasidion infection did not yield any Heterobasidion mycelium, additional sample discs were cut 5 to $10 \mathrm{~cm}$ below the top of those stumps. The discs were prepared and Heterobasidion sp. was isolated as described above. The stump diameters of the final cutting stumps (without bark) ranged from 10 to $38 \mathrm{~cm}$ (mean $26 \mathrm{~cm}$ ).

\subsection{Determination of Heterobasidion Infections in the Subsequent Pine Regeneration}

In spring 2006, the clear-cutting area was planted with one-year-old Scots pine seedlings with 3000 plants/ha. The pine regeneration (generation 2) was first surveyed in the summer of 2011 and since then annually until 2019. Each year (from 2011 to 2019), dead and moribund trees (based on the brown color and loss of needles) were mapped and sampled. Trees with light green or yellowish needles, which were expected to remain alive until the following year, were left untouched. The sample trees were felled, and the stump diameter and the height of the tree were recorded. The base of each sample tree was examined carefully for the presence of fruiting bodies. The area of each fruiting body was calculated by measuring its width and length or diameter depending on the shape of the fruiting body. Sampling for the presence of Heterobasidion mycelia consisted of cutting a disc from the base of the tree 1-2 cm above ground level. A disk from each sample tree was immediately placed in a paper bag and taken to the laboratory. The disks were handled similarly as described above for the previous rotation trees, including the isolation of Heterobasidion mycelium. Because of further studies planned on the experimental site, no isolations were made from fruiting bodies. The coordinates of each disease center, with a horizontal accuracy of $1 \mathrm{~m}$, were recorded using a Global Positioning Systems (GPS) receiver. Moreover, in fall 2019, the number of planted and naturally established seedlings was counted in 15 circular plots each with a radius of $2.52 \mathrm{~m}$ that were evenly distributed throughout the healthy parts of the regeneration. According to the obtained result, the number of pine seedlings in the regeneration area would have been c. 3800 if no Heterobasidion infections had occurred. 


\subsection{Somatic Incompatibility Tests}

To obtain detailed information about the progression of Heterobasidion infections at the study site, the number, size, and spatial distribution of Heterobasidion genets (clones) were identified with the aid of somatic incompatibility tests. For this purpose, agar plugs with the mycelium of two isolates were placed $1 \mathrm{~cm}$ apart on MEA, incubated at room temperature for 3-5 weeks, and the occurrence (or absence) of a demarcation line between the paired isolates was recorded [21]. First, all the isolates from the circular plot in the previous tree generation (generation 1) as well as the isolates from each disease center outside the plot were paired with each other in all combinations. After that, the isolates collected over the years from the pine regeneration (generation 2) within c. $10 \mathrm{~m}$ were paired with each other as well as with the isolates collected from stumps of the previous tree generation located close to them. In all, nearly 8000 pairings were done during the study. The presence of clamp connections to confirm the heterokaryon of Heterobasidion mycelia was checked in unclear cases. Mostly, the characteristic external appearance of heterokaryotic mycelia (compared to more fluffy aerial and less pigmented homokaryotic mycelia), as well as distinctive pairing reactions between heterokaryotic individuals (sparse hyphae or gaps between genetically dissimilar heterokaryotic individuals and a continuous mycelia between genetically similar heterokaryons), indicated that the mycelia isolated from pine wood were heterokaryotic [2,22]. Finally, the species of Heterobasidion was determined with the aid of the Buller phenomenon, that is, a representative from each genet was paired with homokaryotic tester strains of H. annosum s.s. and H. parviporum [2].

\subsection{Measurement of the Soil $p H$}

A relationship between soil $\mathrm{pH}$ and severity of Heterobasidion root rot has been shown in several earlier studies $[23,24]$ but no information about the potential variation of soil pH within a diseased pine stand is available. For this reason, in summer 2019, the soil $\mathrm{pH}$ was measured at 20 disease centers and at 20 healthy points randomly distributed over the experimental stand. When taking soil samples in disease centers, it was ensured that the distance to the nearest healthy tree was at least three meters. Correspondingly, at healthy points, the distance to the nearest infected tree was at least three meters. All soil samples were taken from the uppermost mineral soil 0-10 $\mathrm{cm}$ below the humus layer. Coarse roots were removed from the samples and the $\mathrm{pH}$ was measured electrometrically from a $15 \mathrm{~mL}$ sample suspended in $25 \mathrm{~mL}$ of $\mathrm{H}_{2} \mathrm{O}$ for each soil sample separately.

\subsection{Calculations and Statistics}

To analyze the temporal spread of root rot in the subsequent pine regeneration, the number of seedlings killed by $H$. annosum s.s. and the total number of dead seedlings, as well as the expansion of individual disease centers (by the number of infected trees), were determined as a times series in years between 2011-2019. Differences in the soil pH between the disease centers and healthy parts in the experimental stand were analyzed using a $t$ test to compare the means (Independent Samples $t$ test).

\section{Results}

\subsection{Heterobasidion Root Rot in the Previous Tree Generation}

As a result of a visual evaluation of standing pines, c. $8 \%$ of generation 1 were classified as infected by $H$. annosum s.s. After final cutting, Heterobasidion mycelium was isolated from $79.2 \%$ of the trees classified as diseased (but still living) by visual monitoring. The isolation of H. annosum s.s. from samples of dead pines proved difficult and only $59.3 \%$ of the dead tree samples yielded Heterobasidion mycelium. In addition to diseased and dead trees, $H$. annosum s.s. was isolated from $40 \%$ of the trees without any visible sign of infection (classified as healthy).

In the circular study plot, 55.4 and $9.4 \%$ of the final cutting stumps and older thinning stumps of Scots pine (generation 1) were infected by H. annosum s.s., respectively. Even though increment core samples were taken both from the stump body and the largest 
stump roots, Heterobasidion infections were missed in $38 \%$ of the stumps in which the fungus was later successfully isolated from a disc sample. In total, Heterobasidion mycelium was isolated from 62 pine stumps, that is, ca. $12 \%$ of the mature pines.

Based on the results of the pairing tests, 23 distinct Heterobasidion genets were found in generation 1. Since comprehensive sampling of all stumps was carried out only in the circular study plot, the size of the Heterobasidion genets outside the plot remains unknown. In the $20 \mathrm{~m}$ circular plot, the maximal number of trees infected by an individual Heterobasidion genotype was 17 trees and the mean size of the genets was 3.2 trees. Only isolates of $H$. annosum s.s. (and thus no H. parviporum) were observed.

\subsection{Progression of Heterobasidion Root Rot in the Subsequent Pine Regeneration}

The first 27 pine seedlings killed by Heterobasidion infection were found in the summer of 2011, five years after their planting. However, advanced decay and the occurrence of fruiting bodies indicated that the seedling mortality had probably started in 2010 (Figure 1). During a nine-year monitoring period, 710 dead pine seedlings were recorded in the regeneration area, 38 of which were found to be killed by a causal agent other than $H$. annosum s.s. From the remaining 672 dead pines, the fungus was successfully isolated from 529 seedlings. In an additional 49 cases, fruiting bodies of $H$. annosum s.s. were found and the presence of the fungus was recorded even though no mycelium could be isolated from the disc sample. In addition to these 578 confirmed cases of Heterobasidion infection, we detected 94 dead seedlings most probably also infected by H. annosum s.s. In these cases, the contamination of advanced decay by fast-growing molds and bacteria, or the absence of fungal mycelium due to strongly resinous wood likely prevented the isolation of Heterobasidion mycelium.

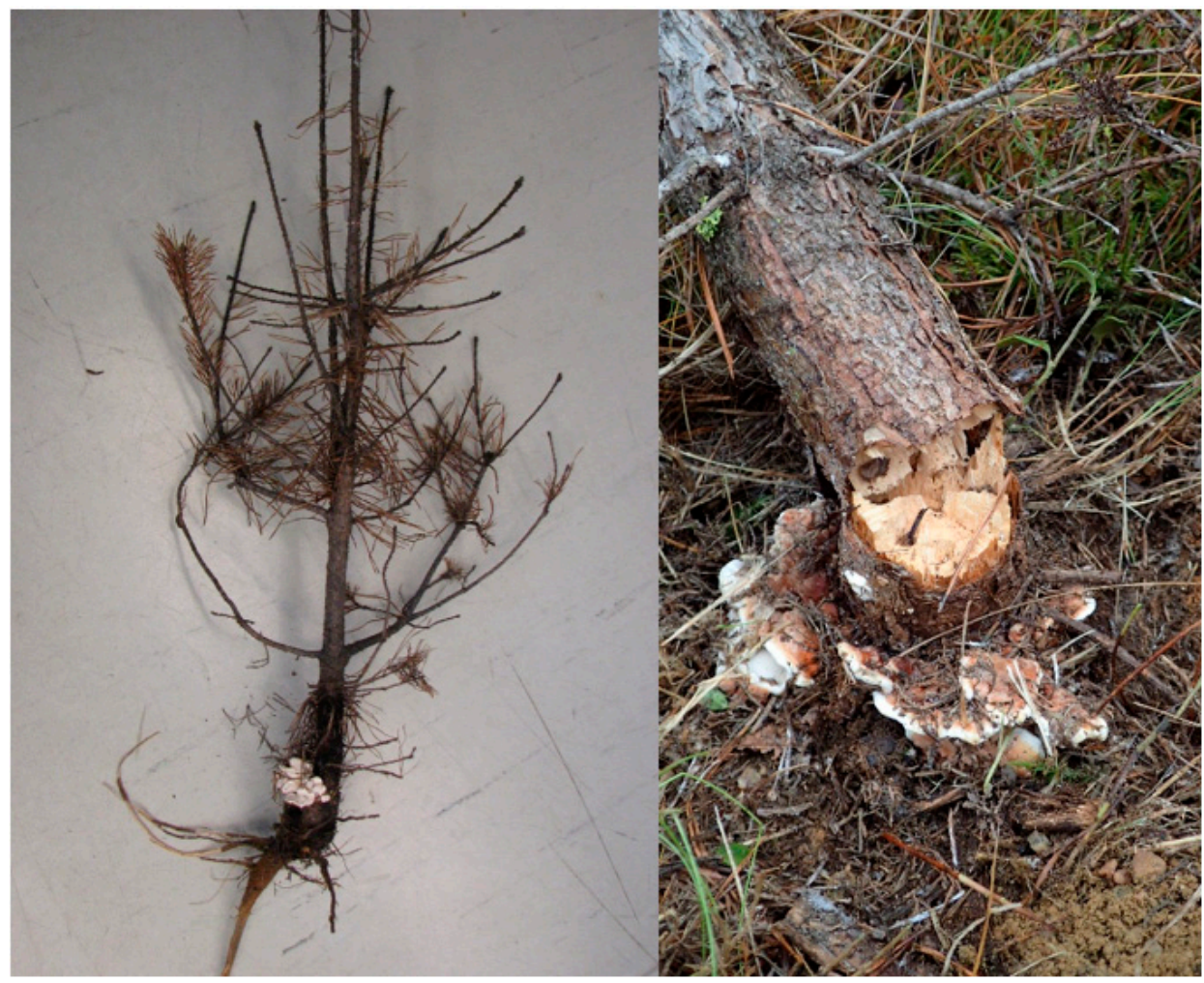

Figure 1. Fruiting bodies of Heterobasidion annosum s.s. on the base of a 5-year-old (on the left) and a 12-year-old pine (on the right).

The smallest seedling killed by Heterobasidion root rot occurred in 2011 and was $21 \mathrm{~cm}$ high (basal diameter $0.9 \mathrm{~cm}$ ) and the biggest one killed was $640 \mathrm{~cm}$ high (basal diameter $11.2 \mathrm{~cm}$ ) and occurred in 2019. The number of seedlings killed was at its highest 
in 2015, nine years after planting, when 166 seedlings were killed during the year, 160 of which were confirmed to have been killed by Heterobasidion root rot. The cumulative number of seedlings killed by $H$. annosum s.s. is shown in Figure 2. In the absence of Heterobasidion infections, the total number of pine seedlings in the study area was estimated to be ca. 3800 indicating that at least ca. 15\% (578 infected trees), but more likely ca. $18 \%(672)$ of the seedlings were killed by Heterobasidion root rot over nine years. In addition to Heterobasidion root rot, seedlings were also killed by competition, moose browsing, Armillaria sp. Infection, and other non-identifiable causative agents; 7, 7, 5, and 19 seedlings, respectively. In 2018 and 2019, Pissodes pini (L.), the larger banded pine weevil, was observed in the lower part of five Heterobasidion infected pine trunks with a diameter at breast height (dbh) over $5 \mathrm{~cm}$.

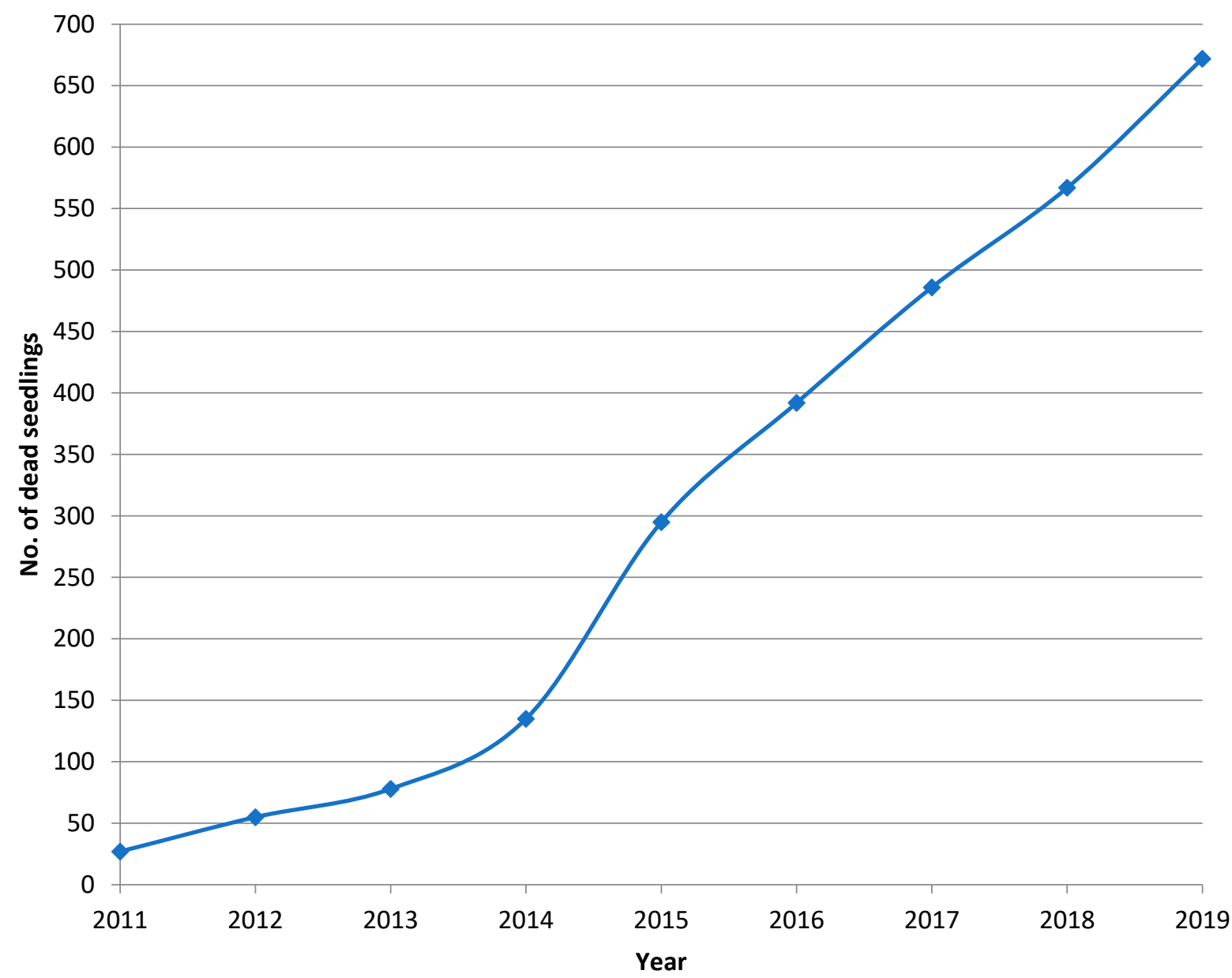

Figure 2. Cumulative mortality of pine seedlings infected by Heterobasidion annosum s.s. (verified and probable infections) on the 1.2 ha regeneration area in the period 2011-2019.

Altogether, 48 disease centers were recorded in the subsequent pine regeneration (Figure 3). Most centers (27) appeared in 2011 and 2012, but several new disease centers (10) were found in 2015 when the highest number of seedlings were killed by H. annosum s.s. The largest disease area (c. $\left.170 \mathrm{~m}^{2}\right)$ consisted of three distinct centers, which had grown together over the years. 


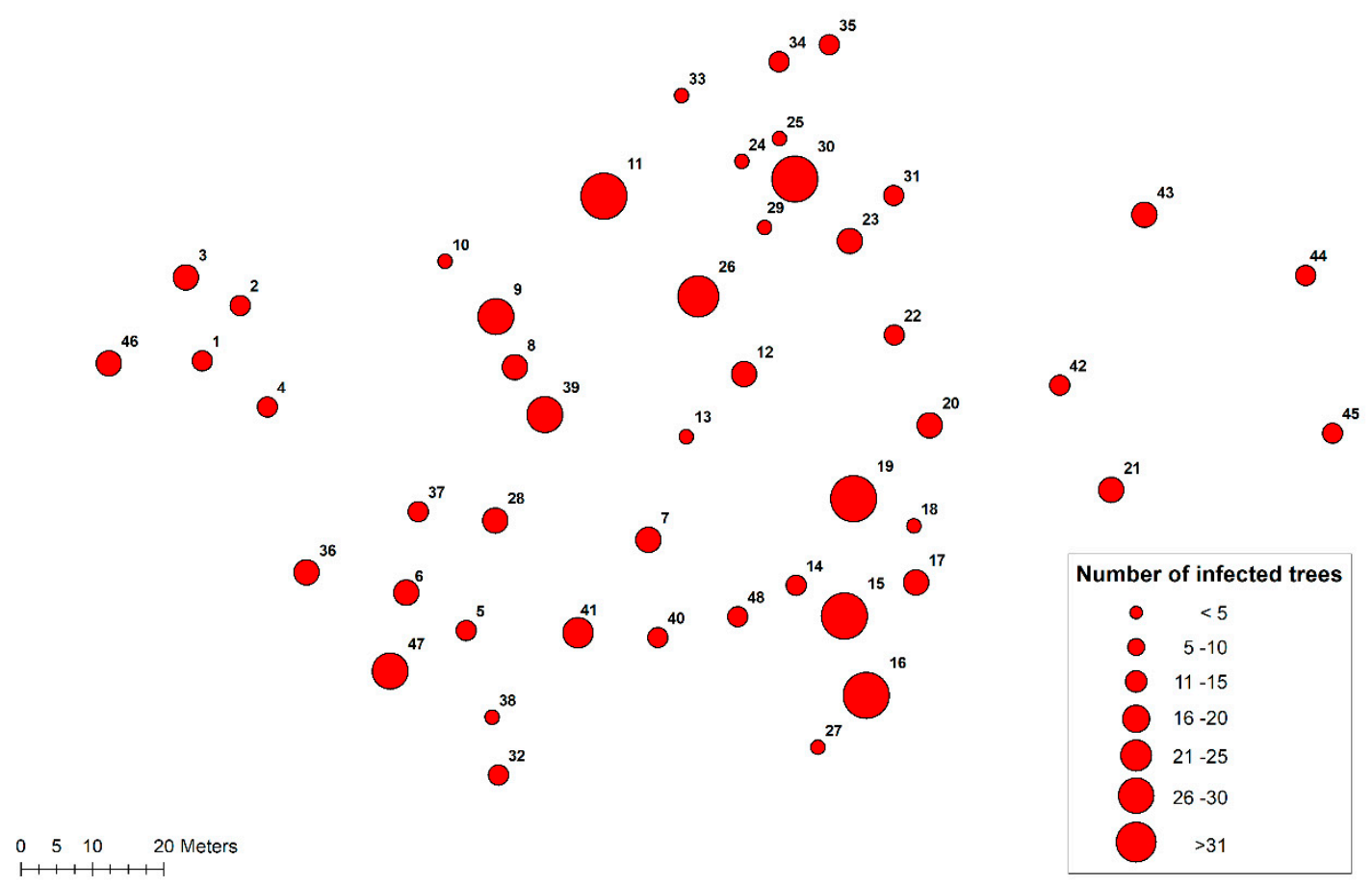

Figure 3. Location of 48 disease centers on the 1.2 ha regeneration area. The size of the circle indicates the number of infected trees in the disease center.

Based on the genotyping of 482 (out of 529) isolates of H. annosum s.s. collected from infected seedlings, 117 fungal genotypes were identified in the subsequent regeneration (generation 2) (Supplementary data, Table S1). Of those seedlings, 38.4\% were infected by a genotype that was also isolated from the stumps of the previous tree generation (generation 1). On average, 2.9 different Heterobasidion genotypes occurred in an individual disease center. In $16.7 \%$ of the disease centers, only one genotype was isolated and $6.3 \%$ of the disease centers were limited to one infected seedling. The maximal number of Heterobasidion genotypes isolated from an individual disease center was eight. The largest Heterobasidion genet by seedling number consisted of four pine stumps of the previous tree generation (generation 1) and 48 seedlings of the subsequent regeneration (generation 2). On average, the genets that could be traced to the previous generation encompassed 26.6 seedlings (generation 2) and 5.4 trees of generation 1, while the average size of the genets that could not be traced to the previous generation was 2.7 (max. 22) seedlings. All identified genets were composed of isolates of H. annosum s.s. (and thus no H. parviporum was isolated). The annual (2012-2019) spreading of the Heterobasidion genets in an exemplar disease center is illustrated in Figure 4.

In 2019, 43 genets (out of 117) were in the spreading stage, 23 of them were old genets, and 20 new genets arisen in 2019.

\subsection{Occurrence of Heterobasidion Fruiting Bodies}

No Heterobasidion fruiting bodies were found on pine stumps of the previous tree generation (generation 1). However, in contrast, fruiting bodies were abundant in the subsequent pine regeneration (generation 2) (Figure 1). In all, Heterobasidion fruiting bodies were found on 362 pine seedlings, located near ground level at the base of diseased trees. In one exceptional case, some small fruiting bodies were found on very thin roots about $20 \mathrm{~cm}$ from the base of the tree. Most of the fruiting bodies were small, a few millimeters in diameter, but also some large fruiting bodies up to $168 \mathrm{~cm}^{2}$ in size were formed on the base of young pine seedlings. The total area of all fruiting bodies (based on the calculated area of each individual fruit body) was ca. $1800 \mathrm{~cm}^{2}$. The first fruiting bodies on seedlings were 
observed five years after planting (2011) but it is likely that most of them had developed in the autumn of the previous year. Some fruiting bodies were also found on the roots of dead heather (Calluna vulgaris L. Hull.) and dead bilberry (Vaccinium myrtillus L.) plants.

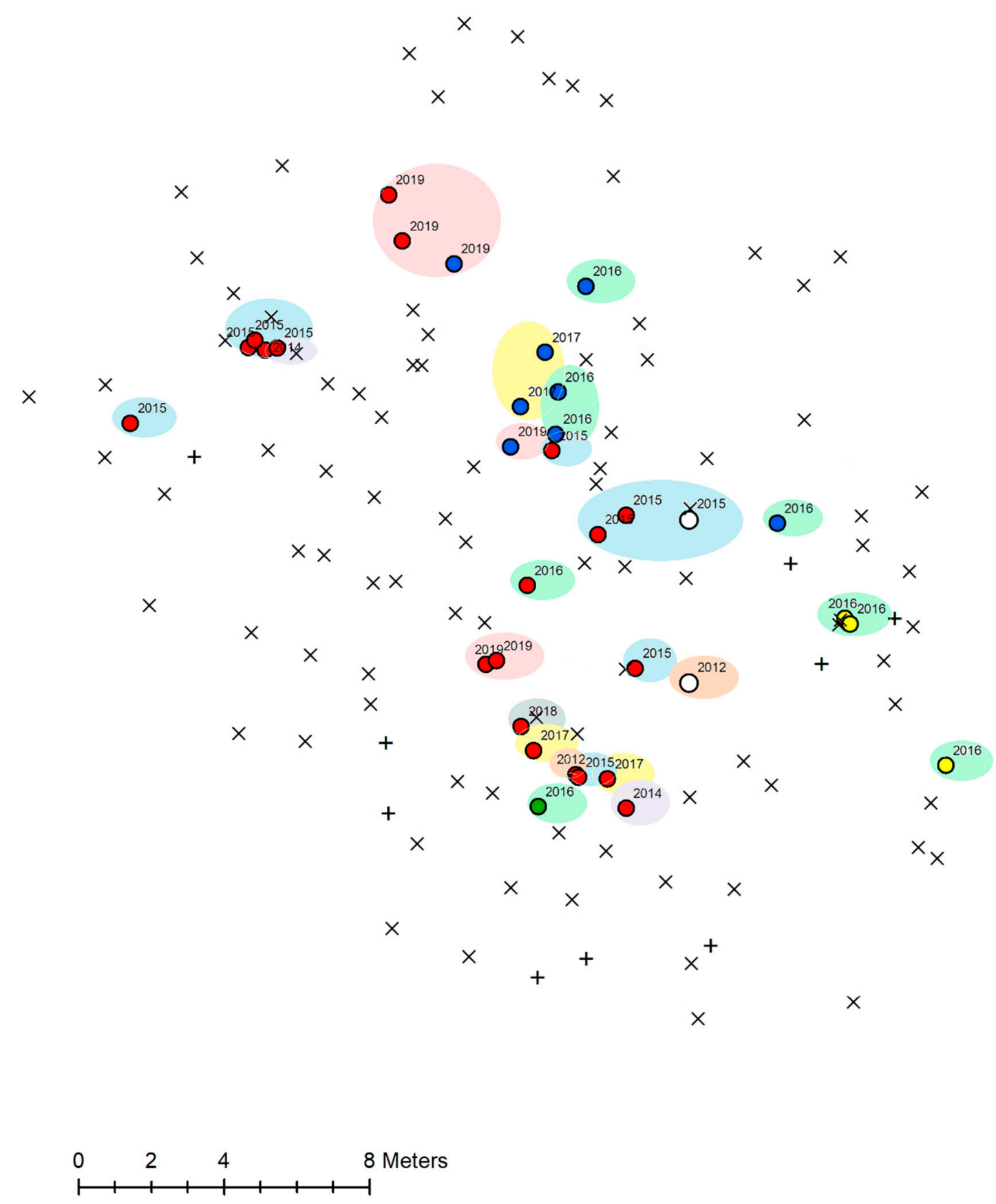

Figure 4. The spatial and temporal distribution of Heterobasidion genets in the disease center DC19 (see the supplementary data, Table S1) in the pine regeneration (generation 2). Circles represent pine seedlings infected by H. annosum s.s.; seedlings infected by the same Heterobasidion genet are marked with a circle of the same color; an open circle indicates that a Heterobasidion genet was not identified. The year next to the circle indicates the year of the seedling's death. The trees that died in the same year are shaded with the same color. The symbol $\times$ represents living, healthy pine seedlings and the + sign living birches. 


\subsection{Soil pH in Disease Centers and Healthy Parts of the Stand}

The soil $\mathrm{pH}$ in the experimental stands varied from 4.1 to 5.1 and was slightly higher in disease centers than in healthy parts around them, $4.7+0.27$ and $4.3+0.16$ (mean + std. deviation), respectively $(p<0.001)$.

\section{Discussion}

\subsection{Incidence of Heterobasidion Root Rot in the Previous Scots Pine Rotation}

The present study showed that the abundance of Heterobasidion root rot in a mature Scots pine stand cannot be reliably assessed based on the external condition of the trees. In particular, those trees with an incipient infection found growing around the margins of the disease centers can be incorrectly classified as healthy according to their crown condition. Similarly, some earlier studies have shown that the visual estimation of root rot in older Scots pine stands can be inaccurate and underestimates the incidence of the disease (e.g., [11,12]). A more reliable method of detecting Heterobasidion root rot is to identify symptoms of infection (resin patches and occasionally decay) on the stump surface immediately after harvesting. Even then, Heterobasidion infections limited to the root system remain undetected [13]. In the present study, no thinnings or other management practices, which could have predisposed the seedlings to direct spore infection, were carried out in the subsequent regeneration (generation 2), suggesting that the stumps of the previous tree generation (generation 1) were the main source of infection. The spore infections of the stumps of the dead seedlings cut during the present study were most probably not significant because these stumps, with very few exceptions, were entirely colonized by H. annosum s.s. In other words, a significant level of mortality in the regeneration evidently reflects widespread Heterobasidion infection in the root systems of the old-rotation trees. Obviously, the previous rotation was much more widely infected than external evaluation or stump sampling suggested. More broadly considered, the prevalence of Heterobasidion root rot in mature pine forests in Finland is likely to be much higher than generally assumed. Taking into account that the fungus will likely benefit from increasing temperatures not only by prolonging the sporulation period but also by accelerating mycelial growth $[7,25]$, the damage caused by Heterobasidion root rot will increase in the future if fungal spreading in pine stands regenerated on infested sites cannot be controlled.

The management history of the previous tree generation (generation 1 ) on the study site is not exactly known and the origin of Heterobasidion infections is unclear. Under the northern conditions of Finland, H. annosum s.s. mycelium advances quite slowly in the roots of mature living pines, that is, on average ca. $12 \mathrm{~cm} /$ year [26], which is probably due to the short growing season and unfavorable conditions for the ectotrophic growth of Heterobasidion mycelium in the outer bark on root surfaces in acidic forest soils $[23,27,28]$. In stump roots and in the roots of dead trees the growth rate of Heterobasidion mycelia may, however, be about twice as fast as it is in the roots of living trees [29]. Assuming that thinnings in the previous stand had accelerated the disease spread, the largest (and probably the oldest) genet with a diameter of ca. $28 \mathrm{~m}$ and consisting of 17 mature trees may have originated at a very early stage of the stand development or possibly already when seed trees had been removed from the previous stand. Due to the small size of the genets, both by tree number and area occupied, most of the genets appear to be younger, and most likely originated as a result of later thinning operations. In any case, the timing of the infection is vague because the size of the genet is not only dependent on the age of colonization but also other factors, such as frequency of root contacts, the occurrence of competing and antagonistic microorganisms in the rhizosphere [27,30], soil properties [23,31,32], and improved resistance of the trees with aging [17,23,24]. Furthermore, differences in the inherent tolerance or susceptibility of Scots pine genotypes to Heterobasidion infections [33,34] may influence the spread rate of the disease. Moreover, the rate of the fungal spread could slow down due to reduced vitality of the Heterobasidion mycelium, for example, due to aging [8] and/or virus infections [35-37]. As shown in an earlier study carried out on the same experimental site [19], $29 \%$ of the Heterobasidion genets and $22 \%$ of the isolates identified in the previous tree generation were infected by dsRNA viruses of the family 
Partitiviridae, which is a considerably higher prevalence of these viruses than is typically observed among isolates of Heterobasidion spp. in culture collections [38] but resembles our findings in H. parviporum genets at a spruce-dominated forest site heavily infested by the pathogen [39].

Mycelial isolates of Heterobasidion strains are necessary to determine the size of fungal genets in a tree stand. This study showed that, compared to Norway spruce, the isolation of Heterobasidion mycelia from older Scots pine trees is more challenging and might be less successful. The patchy occurrence of the pathogen in the pinewood, the infections limited to below ground and the resin accumulation preventing the successful isolation of Heterobasidion mycelium from standing trees may lead to an underestimation of the frequency of infected trees. Moreover, the chance of isolating H. annosum s.s. from a stump or dead tree diminishes considerably over time [40]. In the present study, only $60 \%$ of dead pines in disease centers yielded Heterobasidion mycelia. Thus, Heterobasidion root rot might be a considerably more serious problem than can be deduced from the stand condition, presence of fruiting bodies, or successful fungal isolations.

The number of infected trees, as well as the area occupied by a single fungal genet, can vary greatly depending on the reasons given above. Small genets confined mainly to a single stump have been observed in the first pine generation established on postagricultural soil, indicating a short disease history [41]. So far, the largest genet of $H$. annosum s.s. - up to $48 \mathrm{~m}$ across - has been identified in 50-60-year-old Scots pine stands on former agricultural land, where the disease centers were replanted with Betula pendula [42]. In this Lithuanian study, the maximum number of trees, including both pines and replanted birches infected by a single genet of $H$. annosum s.s. was 30 . In the present study, up to 59 pines (17 stumps of the previous tree generation and 42 pine seedlings) were infected by a single Heterobasidion genotype, which is the maximum reported so far. The number of trees infected by a single genotype may, however, poorly reflect the age of the genet. As shown in the present study, the number of trees infected by a single genotype can be high due to the high regeneration density promoting the vegetative spread of $H$. annosum s.s. among pine seedlings.

\subsection{Progress of Heterobasidion Root Rot in the Subsequent Pine Regeneration}

The early mortality of young seedlings, five years after planting, showed that H. annosum s.s. can colonize very small pine roots, which may therefore act as an efficient means for the disease to spread from the previous to the next stand generation. The individual disease centers showed different patterns of enlargement. Some of the genets expanded constantly year by year, while some of them stopped spreading for 1-3 years, after which they continued to expand again. A few genets progressed for one or two growing seasons and then seemed to stop permanently (see supplementary data) despite the fact the disease centers were surrounded by sufficient numbers of susceptible trees enabling disease spread. Stopped or weakened genotypes may also be a reason that some trees in a disease center escape infection-at least temporarily.

In the present study, only seven Heterobasidion genets in the regeneration could be traced back to the previous tree generation. However, all of the largest genets that had infected four or more trees of the previous generation (generation 1) were also found in the next tree generation (generation 2), which supports the notion that once the Heterobasidion infection is well established on the site, it is likely to persist and cause mortality in the next tree generation. Because not all the stumps in the previous tree generation were sampled, and in some sampled stumps the infection may have been limited to the root system, the number of genets originated from old stumps was probably higher than we could demonstrate. The study site was surrounded by a mature pine forest suffering from Heterobasidion root rot, so it is possible that some genets at the edge of the study site originated from the adjacent forest. However, new spore-derived infections during the final cutting of the previous tree generation (generation 1) are unlikely as the stumps outside the disease centers were treated with urea. 


\subsection{Heterobasidion Populations in Disease Centers}

Typically, pines in an individual disease center are infected by several genetically distinct Heterobasidion individuals [43]. In the present study, $83 \%$ of the centers in the regeneration (generation 2) contained more than one Heterobasidion genotype. Why pines infected by different Heterobasidion genets appear in discrete disease centers is so far unclear. It is possible that individual pine stumps, which are very likely to be the main source of secondary infections, are originally infected by several Heterobasidion genotypes as a result of multiple infections caused by unrelated basidiospores, and more than one Heterobasidion genet might inhabit a stump, and each genet may spread to adjacent trees. This possibility is supported by previous observations of several coexisting Heterobasidion genets on a single pine [41,43] and spruce stumps [44,45]. In the present study, no attempts were made to sample several Heterobasidion isolates from each stump so the alternative of multiple infections cannot be completely excluded. The establishment of new genotypes through recombination or somatic mutations in disease centers is also a possible explanatory factor for the occurrence of multiple genotypes in individual disease centers [46]. Moreover, detailed information is needed about the possible relationship between the spatial soil properties and incidence of Heterobasidion infections, for example, whether increased soil $\mathrm{pH}$ could predispose the roots of pine seedlings to primary spore infections.

Although several genotypes were present in single disease centers, the average number of seedlings infected by a single genotype was rather high, 4.1 seedlings (maximum 48 seedlings). Therefore, to minimize future damage, the vegetative spread of Heterobasidion genotypes should be controlled in young seedling stands.

\subsection{Occurrence of Heterobasidion Fruiting Bodies}

A high number of fruiting bodies were found on the base of infected seedlings. The great majority of Heterobasidion spores remain near the spore source [6,47], so the risk of further spore infections and intensification of the disease in the regeneration area as well as in nearby forests is considerably increased. Thinnings in young stands are generally carried out in the summer using a clearing saw and as there is no mechanized method for stump treatment, the small trees are cut without any control treatment to reduce airborne infection. The thinning of seedling stands will very likely enhance the spread of Heterobasidion root $\operatorname{rot}[48]$.

In addition to pine seedlings, Heterobasidion fruiting bodies were also found on the roots of dead heather (Calluna vulgaris L. Hull.) and bilberry (Vaccinium myrtillus L.) plants located near diseased pine seedlings. Thus, the ability of H. annosum s.s. to infect woody dwarf shrubs, as shown earlier by Laine [15], was also observed in this study. In Poland, even a grass (Elymus repens L.) has been found to be infected by H. annosum s.s. in a young pine stand established on former agricultural land [49]. Although in the present study the fruiting bodies on dwarf shrubs were only single observations, the possibility that these plants might carry over Heterobasidion infections to pine trees needs to be investigated in further studies.

\subsection{Variation of Soil pH in the Regeneration}

Mortality caused by Heterobasidion root rot in pine stands is particularly sensitive to soil $\mathrm{pH}$ [50]. Severe pine mortality and rapid mycelial spread have been reported to occur particularly in sandy soils with a $\mathrm{pH}$ higher than $6.0[23,24,51]$. Despite the low soil $\mathrm{pH}$ in boreal pine forests-in general, less than $4.5[52,53]$ — they can be badly damaged by Heterobasidion root rot indicating that soil $\mathrm{pH}$ may not be the determining factor affecting the incidence of the disease under boreal conditions. On the other hand, the present study showed that, at the stand level, the soil $\mathrm{pH}$ was significantly higher ( 0.4 units) in the disease centers than in the healthy parts around them. Further research is needed to determine whether the elevated $\mathrm{pH}$ is a cause or consequence of the occurrence of Heterobasidion root rot. 


\section{Conclusions}

The investigated study site represents a typical boreal pine habitat in the early stage of Heterobasidion invasion. Although the results cannot be directly generalized to pine stands growing under different conditions with different management and disease history, our study showed that a mature pine stand may be severely infected by H. annosum s.s. even if the damage appears externally minor. This study demonstrated the importance of the mycelial spread of individual Heterobasidion genotypes from the previous to the next tree generation, as well as from seedling to seedling in the regeneration, resulting in annually expanding openings and uneven stand density in the subsequent pine stand. Moreover, the results obtained suggested the high importance of the spore load due to the abundant formation of fruiting bodies on infected seedlings, which poses challenges for the thinning of young pine stands. Taken together, the study highlights the importance of developing a stump treatment method suitable for small thinning stumps and the urgent need for new control measures directed towards the secondary spread of H. annosum s.s. in pine regenerations in order to maintain the productivity of the pine forest on infested sites. Finally, the study also raises new questions regarding spatial differences in soil $\mathrm{pH}$ in infected pine stands, the role of viruses in the fungal spread, and their usability in disease control, as well as the significance of dwarf shrubs for transfer of H. annosum s.s. in pine regeneration.

Supplementary Materials: The following is available online at https://www.mdpi.com/article/10 .3390/f12091289/s1, Table S1: Characteristics of the seedlings killed by Heterobasidion root rot by disease centers.

Author Contributions: Conceptualization T.P., E.J.V., H.N. and J.H.; methodology, T.P.; software, T.P.; validation, T.P., E.J.V., H.N. and J.H.; formal analysis, T.P. and H.N.; investigation, T.P., E.J.V., H.N. and J.H.; resources, T.P. and H.N.; data curation, T.P.; writing—original draft preparation, T.P.; writing—review and editing, T.P., E.J.V., J.H., H.N.; visualization, T.P.; supervision, T.P.; project administration, J.H.; funding acquisition, J.H. All authors have read and agreed to the published version of the manuscript.

Funding: This research was funded by the Natural Resources Institute Finland (project 4100700121100) Added: and by the Academy of Finland (decision number 309896).

Institutional Review Board Statement: Not applicable.

Informed Consent Statement: Not applicable.

Data Availability Statement: Data is contained within the article and available on request from the corresponding author.

Acknowledgments: We thank Ari Rajala, Tapio Nevalainen, and Minna Oksanen for their help in the field surveys and lab work throughout the years, as well as Timo Siitonen for locating the disease centers and Sointu Virkkala for creating the maps.

Conflicts of Interest: The authors declare no conflict of interest.

\section{References}

1. Garbelotto, M.; Gonthier, P. Biology, epidemiology, and control of Heterobasidion species worldwide. Annu. Rev. Phytopathol. 2013, 51, 39-59. [CrossRef]

2. Korhonen, K. Intersterility groups of Heterobasidion annosum. Commun. Inst. For. Fenn. 1978, 94, 1-25.

3. Bendz-Hellgren, M.; Lipponen, K.; Solheim, H.; Thomsen, I.M. The Nordic Countries. In Heterobasidion annosum: Biology, Ecology, Impact and Control; Woodward, S., Stenlid, J., Karjalainen, R., Hüttermann, A., Eds.; CAB International: Wallingford, UK, 1998; pp. 333-345124.

4. Mäkinen, H.; Hallaksela, A.-M.; Isomäki, A. Increment and decay in Norway spruce and Scots pine after artificial logging damage. Can. J. For. Res. 2007, 37, 2130-2141. [CrossRef]

5. Redfern, D.B.; Stenlid, J. Spore dispersal and infection. In Heterobasidion annosum: Biology, Ecology, Impact and Control; Woodward, S., Stenlid, J., Karjalainen, R., Hüttermann, A., Eds.; CAB International: Wallingford, UK, 1998; pp. $105-124$.

6. Kallio, T. Aerial distribution of the root-rot fungus Fomes annosus (Fr.) Cooke in Finland. Acta For. Fenn. 1970, 107, 1-20. [CrossRef] 
7. La Porta, N.; Capretti, P.; Thomsen, I.M.; Kasanen, R.; Hietala, A.M.; Von Weissenberg, K. Forest pathogens with higher damage potential due to climate change in Europe. Can. J. Plant Pathol. 2008, 30, 177-195. [CrossRef]

8. Queloz, V.; Holdenrieder, O. Wie gross wird Heterobasidion annosum s.1.?-Eine Literaturübersicht. Schweiz. Z. Forstwes. 2005, 156, 395-398. [CrossRef]

9. Hodges, C.S. Modes of infection and spread of Fomes annosus. Annu. Rev. Phytopathol. 1969, 7, 247-266. [CrossRef]

10. Fiodorov, N. Eastern Europe and Baltic Countries. In Heterobasidion annosum: Biology, Ecology, Impact and Control; Woodward, S., Stenlid, J., Karjalainen, R., Hüttermann, A., Eds.; CAB International: Wallingford, UK, 1998; pp. 387-403.

11. Kurkela, T. Crown condition as an indicator of the incidence of root rot caused by Heterobasidion annosum in Scots pine stands. Silva Fenn. 2002, 36, 451-457. [CrossRef]

12. Rönnberg, J.; Petrlaité, E.; Nilsson, G.; Pratt, J. Two studies to assess the risk to Pinus sylvestris from Heterobasidion spp. in southern Sweden. Scand. J. For. Res. 2006, 21, 405-413. [CrossRef]

13. Wang, L.Y.; Zhang, J.; Drobyshev, I.; Cleary, M.; Rönnberg, J. Incidence and impact of root infection by Heterobasidion spp., and the justification for preventative silvicultural measures on Scots pine trees: A case study in southern Sweden. For. Ecol. Manag. 2014, 315, 153-159. [CrossRef]

14. Allikmäe, E.; Laarmann, D.; Korjus, H. Vitality assessment of visually healthy trees in Estonia. Forests 2017, 8, 223. [CrossRef]

15. Laine, L. The occurrence of Heterobasidion annosum (Fr.) Bref. in woody plants in Finland. Commun. Inst. For. Fenn. 1976, 90, 1-53.

16. Korhonen, K.; Piri, T. The main hosts and distribution of the $\mathrm{S}$ and P groups of Heterobasidion annosum in Finland. In Proceedings of the 8th IUFRO Conference on Root and Butt Rots, Wik, Sweden; Haikko, Finland, 9-16 August 1993; Johansson, M., Stenlid, J., Eds.; Swedish University of Agricultural Sciences: Uppsala, Sweden, 1994; pp. 260-267.

17. Delatour, C.; von Weissenberg, K.; Dimitri, L. Host resistance. In Heterobasidion annosum: Biology, Ecology, Impact and Control; Woodward, S., Stenlid, J., Karjalainen, R., Hüttermann, A., Eds.; CAB International: Wallingford, UK, 1998 ; pp. 143-166.

18. Cajander, A.K. Forest types and their significance. Acta For. Fenn. 1949, 56, 1-71. [CrossRef]

19. Hyder, R.; Piri, T.; Hantula, J.; Nuorteva, H.; Vainio, E.J. Distribution of viruses inhabiting Heterobasidion annosum in a pinedominated forest plot in southern Finland. Microb. Ecol. 2018, 75, 622-630. [CrossRef] [PubMed]

20. Piri, T.; Korhonen, K.; Sairanen, A. Occurrence of Heterobasidion annosum in pure and mixed spruce stands in southern Finland. Scand. J. For. Res. 1990, 5, 113-125. [CrossRef]

21. Stenlid, J. Population structure of Heterobasidion annosum as determined by somatic incompatibility, sexual incompatibility, and isoenzyme patterns. Can. J. Bot. 1985, 63, 2268-2273. [CrossRef]

22. Hansen, E.M.; Stenlid, J.; Johansson, M. Genetic control of somatic incompatibility in the root-rotting basidiomycete Heterobasidion annosum. Mycol. Res. 1993, 97, 1229-1233. [CrossRef]

23. Rishbeth, J. Observations on the biology of Fomes annosus, with particular reference to East Anglian pine plantations. III. Natural and experimental infection of pines, and some factors affecting severity of the disease. Ann. Bot. 1951, 15, 221-246. [CrossRef]

24. Gibbs, J.N.; Greig, B.J.W.; Pratt, J.E. Fomes root rot in Thetford Forest, East Anglia: Past, present and future. Forestry 2002, 75, 191-202. [CrossRef]

25. Müller, M.M.; Sievänen, R.; Beuker, E.; Meesenburg, H.; Kuuskeri, J.; Hamberg, L.; Korhonen, K. Predicting the activity of Heterobasidion parviporum on Norway spruce in warming climate from its respiration rate at different temperatures. For. Pathol. 2014, 44, 325-336. [CrossRef]

26. Piri, T. Response of compensatory-fertilized Pinus sylvestris to infection by Heterobasidion annosum. Scand. J. For. Res. 2000, 15, 218-224. [CrossRef]

27. Gibbs, J.N. A study of the epiphytic growth habit of Fomes annosus. Ann. Bot. 1967, 31, 755-774. [CrossRef]

28. Korhonen, K.; Stenlid, J. Biology of Heterobasidion annosum. In Heterobasidion annosum: Biology, Ecology, Impact and Control; Woodward, S., Stenlid, J., Karjalainen, R., Hüttermann, A., Eds.; CAB International: Wallingford, UK, 1998; pp. 43-70.

29. Bendz-Hellgren, M.; Brandtberg, P.O.; Johansson, M.; Swedjemark, G.; Stenlid, J. Growth rate of Heterobasidion annosum in Picea abies established on forest land and arable land. Scand. J. For. Res. 1999, 14, 402-407. [CrossRef]

30. Morrison, D.J.; Johnson, A.L.S. Stump colonization and spread of Fomes annosus five years after thinning. Can. J. For. Res. 1978, 8 , 177-180. [CrossRef]

31. Froelich, R.C.; Dell, T.R.; Walkinshaw, C.H. Soil factors associated with Fomes annosus in the Gulf States. For. Sci. 1966, $12,356-361$. [CrossRef]

32. Alexander, S.A.; Skelly, J.M.; Morris, C.L. Edaphic factors associated with the incidence and severity of disease caused by Fomes annosus in loblolly pine plantations in Virginia. Phytopathology 1975, 65, 585-591. [CrossRef]

33. Kovalchuk, A.; Zhu, L.; Keriö, S.; Asiegbu, F.O. Differential responses of Scots pine stilbene synthase and chalcone synthase genes to Heterobasidion annosum infection. For. Pathol. 2017, 47, e12348. [CrossRef]

34. Mukrimin, M.; Kovalchuk, A.; Ghimire, R.P.; Kivimäenpää, M.; Sun, H.; Holopainen, J.K.; Asiegbu, F.O. Evaluation of potential genetic and chemical markers for Scots pine tolerance against Heterobasidion annosum. Planta 2019, 250, 1881-1895. [CrossRef]

35. Jurvansuu, J.; Kashif, M.; Vaario, L.; Vainio, E.J.; Hantula, J. Partitiviruses of a fungal forest pathogen have species-specific quantities of genome segments and transcripts. Virology 2014, 462-463, 25-33. [CrossRef] [PubMed]

36. Vainio, E.J.; Jurvansuu, J.; Hyder, R.; Kashif, M.; Piri, T.; Tuomivirta, T.; Poimala, A.; Xu, P.; Mäkelä, S.; Nitisa, D.; et al. The partitivirus HetPV13-an1 mediates growth debilitation and major alterations in the gene expression of a fungal forest pathogen. $J$. Virol. 2018, 92, e01744-17. [CrossRef] 
37. Kashif, M.; Jurvansuu, J.; Vainio, E.J.; Hantula, J. Alphapartitiviruses of Heterobasidion wood decay fungi affect each other's transmission and host growth. Front. Cell. Infect. Microbiol. 2019, 9, 64. [CrossRef]

38. Vainio, E.J.; Hakanpää, J.; Dai, Y.-C.; Hansen, E.; Korhonen, K.; Hantula, J. Species of Heterobasidion host a diverse pool of partitiviruses with global distribution and interspecies transmission. Fungal Biol. 2011, 115, 1234-1243. [CrossRef]

39. Vainio, E.J.; Müller, M.M.; Korhonen, K.; Piri, T.; Hantula, J. Viruses accumulate in aging infection centers of a fungal forest pathogen. ISME J. 2015, 9, 497-507. [CrossRef]

40. Zaluma, A.; Muižnieks, I.; Gaitnieks, T.; Burneviča, N.; Jansons, Â.; Stenlid, J.; Vasaitis, R. Infection and spread of root rot caused by Heterobasidion spp. in Pinus contorta plantations in Northern Europe: Tree case studies. Can. J. For. Res. 2019, 48, 969-977. [CrossRef]

41. Łakomy, P.; Broda, Z.; Werner, A. Genetic diversity of Heterobasidion spp. in Scots pine, Norway spruce and European silver fir stands. Acta Mycol. 2007, 42, 203-210. [CrossRef]

42. Lygis, V.; Vasiliauskas, R.; Stenlid, J. Planting Betula pendula on pine sites infested by Heterobasidion annosum: Disease transfer, silvicultural evaluation, and community of wood-inhabiting fungi. Can. J. For. Res. 2004, 34, 120-130. [CrossRef]

43. Chase, T.E.; Ullrich, R.C. Sexuality, distribution, and dispersal of Heterobasidion annosum in pine plantations of Vermont. Mycologia 1983, 75, 825-831. [CrossRef]

44. Swedjemark, G.; Stenlid, J. Population dynamics of the root rot fungus Heterobasidion annosum following thinning of Picea abies. Oikos 1993, 66, 247-254. [CrossRef]

45. Johannesson, H.; Stenlid, J. Nuclear reassortment between vegetative mycelia in natural populations of the basidiomycete Heterobasidion annosum. Fungal Genet. Biol. 2004, 41, 563-570. [CrossRef]

46. James, T.Y.; Johansson, B.K.; Johannesson, H. Trikaryon formation and nuclear selection in pairings between heterokaryons and homokaryons of the root rot pathogen Heterobasidion parviporum. Mycol. Res. 2009, 113, 583-590. [CrossRef] [PubMed]

47. Stenlid, J. Regional differentiation in Heterobasidion annosum. In Proceedings of the 8th International Conference on Root and Butt Rots, Wik, Sweden; Haikko, Finland, 9-16 August 1993; Johansson, M., Stenlid, J., Eds.; Sveriges Lantbruksuniv.: Uppsala, Sweden, 1994; pp. 243-248.

48. Jokinen, K. The spread of Heterobasidion annosum and its control using Phlebiopsis gigantea during thinning in the young stands of Scots pine. Folia For. 1984, 607, 1-12, (In Finnish with English Summary).

49. Sierota, Z.; Damszel, M.; Borys, M.; Nowakowska, J.A. The couch grass rhizome with Heterobasidion annosum fruiting bodies in afforested post-agricultural land. For. Pathol. 2016, 46, 376-379. [CrossRef]

50. Stenlid, J.; Redfern, D.B. Spread within the tree and stand. In Heterobasidion annosum: Biology, Ecology, Impact and Control; Woodward, S., Stenlid, J., Karjalainen, R., Hüttermann, A., Eds.; CAB International: Wallingford, UK, 1998; pp. $125-141$.

51. Wallis, G.W. Relation of Fomes annosus Incidence to Soil and Forest Management in East Anglian Pine Plantations; Report on Forest Research: London, UK, 1960; p. 113.

52. Lahti, T.; Väisänen, R.A. Ecological gradients of boreal forests in South Finland: An ordination test of Cajander's forest site type theory. Vegetatio 1987, 68, 145-156. [CrossRef]

53. Tamminen, P. Soil factors. In Forest Condition in a Changing Environment-The Finnish Case; Mälkönen, E., Ed.; Springer: Dordrecht, The Netherlands, 2000; Volume 65, pp. 72-86. [CrossRef] 